\title{
Weathering by tree-root-associating fungi diminishes under simulated Cenozoic atmospheric $\mathrm{CO}_{2}$ decline
}

\author{
J. Quirk ${ }^{1}$, J. R. Leake ${ }^{1}$, S. A. Banwart ${ }^{2}$, L. L. Taylor ${ }^{1}$, and D. J. Beerling ${ }^{1}$ \\ ${ }^{1}$ Department of Animal and Plant Sciences, University of Sheffield, Sheffield S10 2TN, UK \\ ${ }^{2}$ Kroto Research Institute, North Campus, University of Sheffield, Sheffield S3 7HQ, UK
}

Correspondence to: J. Quirk (j.quirk@ sheffield.ac.uk)

Received: 3 September 2013 - Published in Biogeosciences Discuss.: 9 October 2013

Revised: 6 December 2013 - Accepted: 11 December 2013 - Published: 23 January 2014

\begin{abstract}
Trees dominate terrestrial biotic weathering of silicate minerals by converting solar energy into chemical energy that fuels roots and their ubiquitous nutrientmobilising fungal symbionts. These biological activities regulate atmospheric $\mathrm{CO}_{2}$ concentrations $\left(\left[\mathrm{CO}_{2}\right]_{\mathrm{a}}\right)$ over geologic timescales by driving calcium and magnesium fluvial ion export and marine carbonate formation. However, the important stabilising feedbacks between $\left[\mathrm{CO}_{2}\right]_{\mathrm{a}}$ and biotic weathering anticipated by geochemical carbon cycle models remain untested. We report experimental evidence for a negative feedback across a declining Cenozoic $\left[\mathrm{CO}_{2}\right]_{\mathrm{a}}$ range from 1500 to $200 \mathrm{ppm}$, whereby low $\left[\mathrm{CO}_{2}\right]_{\mathrm{a}}$ curtails mineral surface alteration via trenching and etch pitting by arbuscular mycorrhizal (AM) and ectomycorrhizal (EM) fungal partners of tree roots. Optical profile imaging using vertical scanning interferometry reveals changes in nanoscale surface topography consistent with a dual mode of attack involving delamination and trenching by AM and EM fungal hyphae on phyllosilicate mineral flakes. This is consistent with field observations of micropores in feldspar, hornblende and basalt, purportedly caused by EM fungi, but with little confirmatory evidence. Integrating these findings into a process-based biotic weathering model revealed that low $\left[\mathrm{CO}_{2}\right]_{\mathrm{a}}$ effectively acts as a "carbon starvation" brake, causing a three-fold drop in tree-driven fungal weathering fluxes of calcium and magnesium from silicate rock grains as $\left[\mathrm{CO}_{2}\right]_{\mathrm{a}}$ falls from 1500 to $200 \mathrm{ppm}$. The feedback is regulated through the action of low $\left[\mathrm{CO}_{2}\right]_{\mathrm{a}}$ on host tree productivity and provides empirical evidence for the role of $\left[\mathrm{CO}_{2}\right]_{\mathrm{a}}$ starvation in diminishing the contribution of trees and mycorrhizal fungi to rates of biological weathering. More broadly, diminished tree-driven weathering under declining $\left[\mathrm{CO}_{2}\right]_{\mathrm{a}}$ may provide an impor-
\end{abstract}

tant contributory mechanism stabilising Earth's $\left[\mathrm{CO}_{2}\right]_{\mathrm{a}}$ minimum over the past 24 million years.

\section{Introduction}

Throughout their evolutionary history, tree roots have formed ubiquitous symbiotic partnerships with either arbuscular mycorrhizal (AM) or more recently evolved ectomycorrhizal (EM) fungi, with both roots and their associated fungal partners recognised as the dominant biotic drivers of terrestrial mineral weathering (Blum et al., 2002; Bonneville et al., 2009; Cochran and Berner, 1996; Landeweert et al., 2001; Quirk et al., 2012; Rosling et al., 2004; Taylor et al., 2009). The activities of both AM and EM fungi are fuelled by delivery of photosynthate from the host plant into their roots and on to the fungi. Extensive networks of root-associating hyphae extend into the soil to enhance essential nutrient element mass transfers from solid and liquid phases to plants by enhancing the intimacy of mineral contact and absorptive surface areas relative to roots (Smith and Read, 2008; Taylor et al., 2009). The mechanistic basis underpinning mycorrhizal hyphal-mineral interaction is being resolved at the nanometre scale, with recent observations demonstrating structural alterations and mineral surface trenching through the effects of organic ligand exudation, such as siderophores and low-molecular-weight organic compounds, proton extrusion and cation uptake (Bonneville et al., 2009; Gazzè et al., 2012; Saccone et al., 2011). Such effects are most strongly expressed in EM fungi (Lambers et al., 2009; Taylor et al., 2009; Landeweert et al., 2001), which molecular clocks indicate originated 220-135 million years (Ma) ago (Smith and

Published by Copernicus Publications on behalf of the European Geosciences Union. 
Read, 2008; Taylor et al., 2009 and references therein), more than $200 \mathrm{Ma}$ after ancestral AM fungi (Brundrett, 2002; Taylor et al., 2009).

Biological weathering of silicate minerals by roots and mycorrhizal fungi is linked conceptually, and through experimental evidence, to primary productivity and photosynthate fluxes belowground from the canopies of the host trees supporting the fungal symbionts (Cochran and Berner, 1996; Rosling et al., 2004; Smits et al., 2012; Taylor et al., 2009; Andrews and Schlesinger, 2001). Under atmospheric $\mathrm{CO}_{2}\left(\left[\mathrm{CO}_{2}\right]_{\mathrm{a}}\right)$ enrichment (concentrations of $\sim 600 \mathrm{ppm}$ or higher), delivery of photosynthate to both AM and EM fungal partners can increase, fuelling expansion of fungal networks, increased delivery of labile carbon into soils, and for EM partnerships, greater exudation of low-molecularweight organic compounds and chelating agents (Alberton et al., 2005; Drigo et al., 2010; Drigo et al., 2013; Fransson, 2012; Johansson et al., 2009; Pritchard et al., 2008). Intensified chemical dissolution of mineral resources by mycorrhizal networks of trees under increasing $\left[\mathrm{CO}_{2}\right]_{\mathrm{a}}$ likely accelerated Earth's biological weathering engine and $\mathrm{CO}_{2}$ sequestration to regulate climate during geologic intervals of elevated $\left[\mathrm{CO}_{2}\right]_{\mathrm{a}}$ over the past $400 \mathrm{Ma}$ (Berner et al., 1983; Taylor et al., 2009, 2012; Volk, 1987). However, the effects of the Cenozoic $\left[\mathrm{CO}_{2}\right]_{\mathrm{a}}$ decline from 1500 to $200 \mathrm{ppm}$ beginning $35 \mathrm{Ma}$ ago (Beerling and Royer, 2011; Pagani et al., 2011) on plant-driven weathering has not been investigated experimentally.

Geochemical carbon cycle models (Berner et al., 1983; Berner, 2006; Volk, 1987) invoke stabilising feedbacks between $\left[\mathrm{CO}_{2}\right]_{\mathrm{a}}$ and weathering by forests, whereby falling $\left[\mathrm{CO}_{2}\right]_{\mathrm{a}}$ leads to diminished $\mathrm{Ca}^{2+}$ and $\mathrm{Mg}^{2+}$ ion release from terrestrial silicate rocks into the oceans. This in turn reduces marine carbonate deposition, and weakens the long-term sink for $\left[\mathrm{CO}_{2}\right]_{\mathrm{a}}$ (Pagani et al., 2009). Critically, these models are not underpinned by the empirical evidence required to resolve the effects of low $\left[\mathrm{CO}_{2}\right]_{\mathrm{a}}$ on biological weathering processes. This includes understanding of tree-mycorrhiza functioning during episodes of $\left[\mathrm{CO}_{2}\right]_{\mathrm{a}}$ drawdown to within the narrow range of 180-200 ppm that defines Earth's Cenozoic $\left[\mathrm{CO}_{2}\right]_{\mathrm{a}}$ minimum over the past $24 \mathrm{Ma}$.

We report results from controlled-environment growth chamber experiments testing the hypothesised $\left[\mathrm{CO}_{2}\right]_{\mathrm{a}}$ regulation of fungal mineral weathering mediated by AM and EM tree species. We grew saplings of a gymnosperm, coast redwood (Sequoia sempervirens D. Don.), and an angiosperm, field maple (Acer campestre L.), that form AM partnerships alongside an angiosperm, silver birch (Betula pendula Roth.), which associates with EM fungi. These species were selected because they belong to families known to form either AM or EM symbioses and have molecular clock phylogenetic ages dating from the mid-Cenozoic (>36 Ma ago) or earlier (Crisp and Cook, 2011; Wikström et al., 2001). Saplings were cultivated in individual pots alongside plantfree control treatments at three closely regulated $( \pm 4 \%)$
$\left[\mathrm{CO}_{2}\right]_{\mathrm{a}}$ concentrations of 1500,500 and $200 \mathrm{ppm}$, encompassing the upper and lower bounds of the Cenozoic (Beerling and Royer, 2011), and otherwise identical growth conditions.

To isolate the weathering effects of mycorrhizal hyphae on the silicate rocks and minerals, we buried uniform-sized grains of basalt as a source of macronutrients (phosphorus, iron, calcium and magnesium) and flakes of potassiumbearing muscovite within each pot in mesh-walled rootexcluding bags. We measured the lengths of hyphae that were in direct contact with the basalt grains and corrected them for background non-mycorrhizal fungi observed in plant-free control treatments as an index of AM and EM network size and hyphal interaction with rocks and minerals. We employ vertical scanning interferometry to optically profile the surface micro-topography of the muscovite flakes, enabling us to characterise the physical alteration of the mineral surface following active colonisation by fungi.

\section{Methods}

\subsection{Experimental design}

One-year-old Sequoia sempervirens, Acer campestre and Betula pendula saplings were obtained from a UK nursery and cultivated alongside plant-free controls in pots $(18 \mathrm{~cm}$ diameter; approx. $4.5 \mathrm{~L})$ filled with $1: 1(v: v)$ Chelmsford "52" sand (WBB Minerals, Cheshire, UK) and potting compost (Levington M3; Scotts, Ipswich, UK). The substrate was mixed with $\sim 1 \%(w: v)$ mycorrhizal inoculum consisting of soil and root material obtained from beneath mature stands of the same species at the National Arboretum, Westonbirt, UK. This ensured that tree root systems were exposed to natural species-specific consortia of mycorrhizal fungi and other soil microorganisms. The substrate in plant-free control treatments also contained the mycorrhizal inocula. Mycorrhizal colonisation of roots was confirmed, but not formally quantified, for each test species at the end of the experiment and the trees were well colonised by mycorrhizal fungi. Prior to potting, fresh weights of the trees were taken following removal of adhering compost from the roots. The trees $(n=3$ per species per $\left[\mathrm{CO}_{2}\right]_{\mathrm{a}}$ treatment) were randomly distributed between matched controlled-environment growth chambers (Conviron BDW40; Controlled Environments Ltd. Manitoba, Canada) and grown at 200, 500 or $1500 \mathrm{ppm}\left[\mathrm{CO}_{2}\right]_{\mathrm{a}}$ and otherwise constant growth conditions of $80 \%$ relative humidity, $18 / 20^{\circ} \mathrm{C}$ night/day cycle with a $14 \mathrm{~h}$ photoperiod. Light intensity at the canopy was $200 \mu \mathrm{mol} \mathrm{m}^{-2} \mathrm{~s}^{-1}$ for the entirety of the $14 \mathrm{~h}$ photoperiod and duration of the six-month growth period (Supplement Table S1).

The low $\left[\mathrm{CO}_{2}\right]_{\mathrm{a}}$ treatment was maintained by routing the chamber air inlet via a filter unit packed with soda lime (Sofnolime; Molecular Products, Essex, UK) fixed to the exterior of the chamber, which scrubbed $\mathrm{CO}_{2}$ from the air. The 
$\left[\mathrm{CO}_{2}\right]_{\mathrm{a}}$ level was controlled at set point using a $\mathrm{CO}_{2}$ sensor (Carbocap GMP242, Vaisala, Finland) linked to a feedback system regulating chamber air inlet between the soda lime scrubbing unit and bursts of ambient air, and was independently verified with an infrared gas analyser (IRGA) (LI6400; Li-COR, Homburg, Germany). The soda lime was replaced monthly before chamber $\left[\mathrm{CO}_{2}\right]_{\mathrm{a}}$ began to increase. All trees were of comparable biomass prior to their introduction to experimental conditions (Supplement Table S2). Pots were well watered with reverse osmosis water and their chamber positions rotated weekly.

\subsection{Calculated main stem biomass gain}

We used digital photographs of each tree taken at the start of the experiment and again after the six-month growth period to obtain stem length and diameter at the base and crown (highest point of main stem) with ImageJ 1.43 software (National Institutes of Health, Bethesda, Maryland, USA). Stem volume was calculated using $V=(\pi l / 12)\left(b^{2}+b c+c^{2}\right)$, where $l$ is stem length, $b$ is stem diameter at the base, and $c$ is stem diameter at the crown. Pre- and post-treatment stem biomass was estimated using measured mean stem density values obtained for each species at the end of the experiment (Sequoia: $0.73 \mathrm{~g} \mathrm{~cm}^{-3} \pm 0.08$; Acer: $0.60 \mathrm{~g} \mathrm{~cm}^{-3} \pm 0.10$; Betula: $\left.0.41 \mathrm{~g} \mathrm{~cm}^{-3} \pm 0.11\right)$.

\subsection{Root-excluding mesh bags}

Tertiary basalt from Northern Ireland was crushed using a hammer and ball mill, sieved into two size fractions $(0.25-$ $0.50 \mathrm{~mm}$ and $0.50-1.00 \mathrm{~mm})$, rinsed in deionised water $(1$ : $100 w: v$ ) until the water was visibly clear (approx. eight rinses) and dried at $50{ }^{\circ} \mathrm{C}$. The two grain size fractions were weighed into $2.5 \mathrm{~g}$ portions and sealed into $50 \mathrm{~mm} \times 50 \mathrm{~mm}$ right-angled triangle mesh-walled bags $(35 \mu \mathrm{m}$ pore size woven nylon; Plastok Associates Ltd. Birkenhead, Wirral, UK) using a heat sealer to melt and fuse the edges. The mesh walls permitted fungal hyphae and soil pore waters to penetrate and interact with the contents, but prevented access by roots. Duplicate basalt-filled mesh bags were inserted into each pot to a depth of $5 \mathrm{~cm}$ and recovered after 185 days of incubation. Previously published X-ray fluorescence data for the basalt used here highlight its importance as a source of macronutrient elements for the trees and mycorrhizal networks in our experiment: $\mathrm{P}_{2} \mathrm{O}_{5}(0.29 \% \mathrm{wt}), \mathrm{CaO}(10.37 \% \mathrm{wt}), \mathrm{MgO}$ (8.10\%wt), $\mathrm{K}_{2} \mathrm{O}(0.29 \% \mathrm{wt})$ and $\mathrm{Fe}_{2} \mathrm{O}_{3}(11.93 \% \mathrm{wt})$; the $\mathrm{SiO}_{2}$ content of the basalt is $44.22 \%$ wt (Quirk et al., 2012).

\subsection{Hyphal networks colonising rock grains}

Basalt sub-samples $(2 \mathrm{~g})$ from mesh bags were sonicated for 10 min (Branson B32 sonic bath; Danbury CT, USA) in a $100 \mathrm{~mL}$ conical flask with $30 \mathrm{~mL}$ of deionised water to release adhering hyphae from the grains into solution. Aliquots $(5 \mathrm{~mL})$ of the suspension were filtered through $25 \mathrm{~mm}$ diameter, $0.45 \mu \mathrm{m}$ pore size gridded cellulose Whatman ${ }^{\circledR}$ membrane filters. The fragments of external hyphae retained on filters were stained with $2 \mathrm{~mL}$ of Trypan blue lacto-phenol $\left(1.6 \mathrm{mg} 100 \mathrm{~mL}^{-1}\right.$ Trypan Blue $\left[\mathrm{C}_{34} \mathrm{H}_{24} \mathrm{~N}_{6} \mathrm{O}_{14} \mathrm{~S}_{4} \mathrm{Na}_{4}\right], 200 \mathrm{mg} 100 \mathrm{~mL}^{-1}$ phenol $\left[\mathrm{C}_{6} \mathrm{H}_{5} \mathrm{OH}\right], 25 \%$ lactic acid $\left[\mathrm{C}_{3} \mathrm{H}_{6} \mathrm{O}_{3}\right], 50 \%$ glycerol $\left[\mathrm{C}_{3} \mathrm{H}_{5}[\mathrm{OH}]_{3}\right]$ and $25 \%$ deionised water) for $10 \mathrm{~min}$. Excess stain was rinsed through the filter apparatus with deionised water and hyphal lengths were measured using a modified line-intersect technique at 200 times magnification (Wallander et al., 2004). We did not observe aggregated linear hyphal structures within the mesh bags for any of the treatments.

Detailed microscopy of the hyphae colonising basalt from Sequoia and Acer treatments confirmed the typical anatomical features of AM fungi, including ready staining with Trypan Blue lacto-phenol, angular projections, terminal spore formation and the general absence of septa (Smith and Read, 2008). From Betula treatments, predominantly basidiomycotean fungi that often form EM partnerships with roots were identified through diagnostic features such as darker pigmentation and melanisation of the hyphal walls and the presence of septa and clamp connections (Smith and Read, 2008). We determined the extent of active hyphal networks by correcting for the background hyphal lengths associated with the basalt in plant-free control treatments that represent freeliving, saprotrophic fungal populations. Hyphal lengths per unit weight of dry basalt grains in plant-free controls were $0.59 \pm 0.08 \mathrm{~m} \mathrm{~g}^{-1}$ at $200 \mathrm{ppm}, 0.68 \pm 0.07 \mathrm{~m} \mathrm{~g}^{-1}$ at $500 \mathrm{ppm}$ and $0.61 \pm 0.10 \mathrm{mg}^{-1}$ at $1200 \mathrm{ppm}$ (error is $\pm \mathrm{SEM}$ ). Oneway analysis of variance showed no effect of $\left[\mathrm{CO}_{2}\right]_{\mathrm{a}}$ on hyphal lengths colonising basalt grains in control treatments $\left(F_{2,6}=0.27 ; P=0.77\right)$.

\subsection{Characterisation of mineral surface alteration}

Mirau vertical scanning interferometry (VSI) uses white light reflected from a reference mirror that combines with light reflected from a sample surface to produce interference fringes, where best contrast interference occurs at the point of best focus. This "interference" signal is measured at fixed nanoscale intervals as the vertical axis of the instrument moves through focus. As white light has a short coherence length, interference fringes are present only over a shallow depth for each focus point. The vertical position corresponding to peak interference is used to calculate sample surface heights with nanometre vertical resolution (Lüttge et al., 1999). Moreover, using light to characterise surface topography avoids many of the analytical artefacts resulting from the physical mineral surface probing involved in atomic force microscopy, for example (Buss et al., 2007). Each scan produces an $X Y$ data array where each pixel corresponds to surface height $(Z)$ relative to the mean surface plane where $Z$ is equal to zero.

Here, approximately four flakes of muscovite $(\sim 4 \mathrm{~mm} \times 4 \mathrm{~mm})$ from Krantz (Bonn, Germany) were embedded in silicone (commercially available silicone 
sealant) and mounted on $26 \mathrm{~mm} \times 4 \mathrm{~mm}$ glass "VSI slides" (Supplement Fig. S1). Muscovite is an aluminium phyllosilicate mineral ideally suited to such investigations because it yields near atomically smooth cleavage surfaces and is easy to handle with low rates of delamination and loss of the uppermost layer of the mineral once embedded in the silicone. Prior to burial, the surface of each muscovite flake was cleaned first using $\sim 200 \mu \mathrm{L} 1 \%$ sodium dodecyl sulfate (SDS) and lens tissue, followed by lens tissue wetted with deionised water (Buss et al., 2007). The VSI slides were mounted on an automated stage platform and randomly selected localities (500 times magnification, $126 \mu \mathrm{m} \times 94 \mu \mathrm{m}$ scanned area, $640 \mathrm{px} \times 480 \mathrm{px}$ array) on the surface of each mineral flake were scanned using a Wyko NT9100 VSI instrument (Bruker AXS, Madison WI, USA) positioned on a vibration-minimising air table. We obtained the root-mean-square (rms) roughness (Buss et al., 2007) of each surface location ( $n=2$ surface locations on each piece of muscovite) using the instrument's analytical software (Vision 4.10; Bruker AXS, Madison WI, USA) following Eq. (1):

RMS roughness $=\sqrt{\frac{1}{M N} \sum_{j=1}^{M} \sum_{i=1}^{N} Z^{2}\left(x_{i} y_{j}\right)}$,

where $M$ and $N$ are the number of data points in the $x$ and $y$ directions of the data array $(640 \mathrm{px} \times 480 \mathrm{px})$, and $Z$ is the surface height relative to the reference mean plane. As the height values are squared, the development of low points, such as trenches, on the mineral surface over the experiment can be resolved more easily (Buss et al., 2007). Each scan location has known stage coordinates that, in combination with the automated platform and slide mount, allow for precise relocation and re-characterisation of surface topography at each scan location after burial in the pots.

The VSI slides were buried along with $0.5 \mathrm{~g}$ of crushed basalt $(0.50-1.00 \mathrm{~mm}$ grain size) in parallel with the rootexcluding mesh bags used to study hyphal colonisation. After 185 days the slides were recovered, cleaned with lens tissue wetted with $1 \%$ SDS and deionised water as described above and their RMS roughness remeasured. We used the ratio of the post-experiment and pre-experiment RMS roughness to calculate a metric of muscovite mineral surface alteration associated with each pot in the experiment, including the plantfree control pots $\left(n=3\right.$ per species, per $\left.\left[\mathrm{CO}_{2}\right]_{\mathrm{a}}\right)$. We corrected the roughness ratios obtained for each tree by subtracting the muscovite roughness ratios obtained from samples in plant-free control pots. Roughness ratios in control treatments were independent of $\left[\mathrm{CO}_{2}\right]_{\mathrm{a}}(200 \mathrm{ppm}: 2.0 \pm 0.5$; 500 ppm: $2.1 \pm 0.8 ; 1500$ ppm: $2.1 \pm 0.2 ; F_{2,6}=0.03 ; P=$ 0.967 ) and demonstrate a degree of surface roughness increase under plant-free conditions associated with soil pore waters and free-living populations of microorganisms.

\subsection{Fungal trenching of muscovite}

Once the post-experiment RMS roughness measurement was made, each piece of muscovite was analysed for evidence of hyphal trenches. We identified trenches as linear features with characteristics consistent with fungal hyphal morphology, such as diameter, branching patterns, angular projections and terminal spore formation. Where hyphal trenching had occurred, measurement of the dimensions (width and depth) of surface trenches was undertaken using $\mathrm{Vi}$ sion 4.10 software. Two-dimensional transects were analysed at approximately $20 \mu \mathrm{m}$-spaced intervals at right angles to the linear trenches, allowing for assessment of the width at the top of the trench and maximum depth relative to the surrounding planar surface. Trench profiles exhibited a Vshaped morphology in cross section, so we used trench width and depth measurements to estimate trench cross-sectional areas at each intersection based on the area of a triangle (area $=0.5 \times$ width $\times$ depth). We obtained mean trench dimensions for each pot that demonstrated evidence of mineral surface trenching.

\subsection{Canopy transpiration}

Atmospheric $\mathrm{CO}_{2}$ regulation of canopy transpiration has implications for soil moisture content and mineral weathering rates, and this effect is built into the process-based weathering model framework. After five months' acclimation, the saplings were watered to field capacity and the soil was covered in polyvinyl chloride (PVC) sheeting (Caterwrap; Wrap Film Systems, Telford, UK) to prevent evaporation from the soil surface. Over the following week, all pots were weighed twice daily to calculate canopy transpiration. The vapour pressure deficit (VPD) of each growth chamber was calculated using the mean photoperiod temperature and relative humidity (Yoder et al., 2005). Canopy conductance $\left(G_{\mathrm{w}}\right)$ was calculated as transpiration ( $\mathrm{mol} \mathrm{H}_{2} \mathrm{O}$ tree ${ }^{-1} \mathrm{~s}^{-1}$ ) divided by daytime VPD $(0.47 \mathrm{kPa})$ for each tree.

\subsection{Process-based modelling of mycorrhizal mineral weathering}

We modified a leading weathering model (Taylor et al., 2011, 2012) to calculate weathering fluxes from the hyphosphere within basalt-filled mesh bags for each treatment in response to $\left[\mathrm{CO}_{2}\right]_{\mathrm{a}}$ following a series of established assumptions (Taylor et al., 2011). The model is driven by the nutrient ion uptake required to support tree net primary productivity (NPP), along with diffusion of soil $\mathrm{CO}_{2}$, as influenced by $\left[\mathrm{CO}_{2}\right]_{\mathrm{a}}$ and respiration, and, for EM networks only, organic acid exudation (van Hees et al., 2006). NPP was estimated from stem biomass gain, following a stoichiometric assumption that half the mass was carbon (Zhang et al., 2009), with all parts of the pot contributing equally to the nutrition of the organisms. For temperate and boreal tree species, respiration 
is $6 \times$ NPP (Malhi et al., 1999), so that gross primary productivity (GPP) is $7 \times$ NPP. We applied an organic acid exudation function of $0.2 \%$ of GPP by EM hyphae (van Hees et al., 2006) and assumed the negative charge of each organic anion (treated as oxalate) was balanced by protons (Casarin et al., 2003).

We defined the hyphosphere within the mesh bags for basalt under the influence of hyphae, which is determined by the measured hyphal lengths colonising basalt grains and a hyphal radius of $1.4 \mu \mathrm{m}$ (van Hees et al., 2006). Like the rhizosphere, which extends up to several millimetres from fine roots of sub-millimetre radius (Nye, 1981), we consider the hyphosphere to extend $5 \mu \mathrm{m} \times 1.4 \mu \mathrm{m}$ from the hyphal surface (Taylor et al., 2011). This hyphosphere is acidified by the uptake of nutrient cations and by the protons exuded with organic anions. Because the model calculates weathering based on the $\mathrm{pH}$ and oxalate concentration of the water interacting with mineral surfaces following well-established reaction mechanisms (Brantley, 2008), it requires moisture content and mineral surface area. We interpolated moisture content at four equally spaced $21 \mathrm{~h}$ time steps using starting and ending values for one watering cycle calculated using the canopy transpiration rates of our saplings. A geometric surface area of $72 \mathrm{~cm}^{2} \mathrm{~g}^{-1}$ derived from the particle size distribution of our basalt grains, scaled with the roughness ratio data for muscovite normalised to the $500 \mathrm{ppm}$ treatment for each species, allowed for conversion of calculated weathering rates (per unit surface area) to hyphosphere weathering fluxes for each treatment. X-ray diffraction analysis on samples of our test rock was consistent with an olivinepoor tholeittic flood basalt, so the calcium- and magnesiumbearing phases modelled are plagioclase (anorthite 50\%), augite and orthopyroxene (Taylor et al., 2011).

\subsection{Statistics}

We verified that no differences in initial biomass between $\left[\mathrm{CO}_{2}\right]_{\mathrm{a}}$ treatments existed prior to the introduction of saplings into their respective growth $\left[\mathrm{CO}_{2}\right]_{\mathrm{a}}$ regimes using one-way ANOVA testing for $\left[\mathrm{CO}_{2}\right]_{\mathrm{a}}$ within each species following a general linear model factorial design in Minitab 12.21 (Supplement Table S2). AM and EM plant-freecorrected hyphal colonisation of basalt grains, the plant-freecorrected roughness ratio of the muscovite flakes, calculated stem mass gain, root dry weight and total plant dry weight at the end of the experiment were all subjected to two-way ANOVA testing for effects of species type and $\left[\mathrm{CO}_{2}\right]_{\mathrm{a}}$. The absence of $\left[\mathrm{CO}_{2}\right]_{\mathrm{a}}$ effects on the muscovite surface roughness ratio in plant-free control pots was verified with a oneway ANOVA testing for effects of $\left[\mathrm{CO}_{2}\right]_{\mathrm{a}}$. The dimensions (width, depth and cross-sectional area) of the hyphal trench features on the surface of the muscovite flakes (based on multiple transects per trench feature per flake) were averaged $\left(n=3\right.$ per species, per $\left.\left[\mathrm{CO}_{2}\right]_{\mathrm{a}}\right)$ and subjected to one-way ANOVA testing for effects of species type.

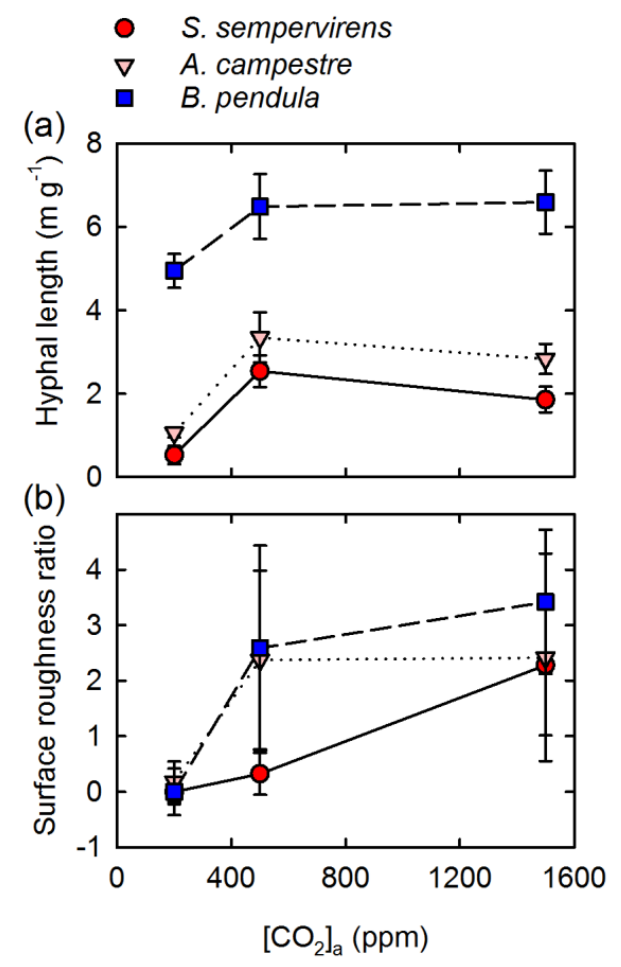

Fig. 1. $\left[\mathrm{CO}_{2}\right]_{\mathrm{a}}$-regulated hyphal colonisation and mineral surface alteration. (a) Mycorrhizal hyphal lengths colonising basalt grains and (b) muscovite roughness ratios (see Methods), decrease with falling $\left[\mathrm{CO}_{2}\right]_{\mathrm{a}}$. All values are mean $\pm \mathrm{SEM}$.

\section{Results and discussion}

\subsection{Hyphal colonisation of basalt rock grains}

After six months under the different $\left[\mathrm{CO}_{2}\right]_{\mathrm{a}}$ treatments, $\mathrm{AM}$ and EM hyphal colonisation of basalt grains was significantly lower for all three tree species experiencing the late Cenozoic $\left[\mathrm{CO}_{2}\right]_{\mathrm{a}}$ minimum of $200 \mathrm{ppm}$ compared to higher $\left[\mathrm{CO}_{2}\right]_{\mathrm{a}}$ treatments $\left(F_{2,18}=6.36 ; P=0.008\right)$ (Fig. 1a). AM fungal networks supported by Sequoia and Acer saplings decreased by $20-40 \%$ at $200 \mathrm{ppm}\left[\mathrm{CO}_{2}\right]_{\mathrm{a}}$, and EM fungal networks with Betula saplings decreased by $25 \%$, relative to 500 and $1500 \mathrm{ppm}\left[\mathrm{CO}_{2}\right]_{\mathrm{a}}$. This reflects reductions in carbon delivery from roots to mycorrhizal fungi as $\left[\mathrm{CO}_{2}\right]_{\mathrm{a}}$ approaches the Cenozoic minimum of $200 \mathrm{ppm}$. The decline in $\left[\mathrm{CO}_{2}\right]_{\mathrm{a}}$ from $1500-500 \mathrm{ppm}$ was not associated with decreased hyphal colonisation of the basalt for any species (Fig. 1a). Across the three $\left[\mathrm{CO}_{2}\right]_{\mathrm{a}}$ treatments, EM fungi maintained significantly greater colonisation of basalt than those of AM trees $\left(F_{2,18}=32.27 ; P<0.0001\right)$ (Fig. 1a), consistent with field evidence from beneath mature stands of gymnosperm and angiosperm trees associated with both mycorrhizal types (Quirk et al., 2012). Low $\left[\mathrm{CO}_{2}\right]_{\mathrm{a}}$-regulated declines in $\mathrm{AM}$ and $\mathrm{EM}$ fungal network sizes diminished the intensity of their subsequent interactions with minerals 
(Fig. 1b). We characterised the intensity of hypha-mineral interactions using VSI optical profile measurements of changes in nanoscale surface topography of muscovite flakes coburied with the basalt.

\subsection{Mineral surface alteration}

Based on our VSI analyses of muscovite, decreasing $\left[\mathrm{CO}_{2}\right]_{\mathrm{a}}$ was significantly and non-linearly linked to lower mineral surface roughness ratios across all tree species $\left(F_{2,18}=4.55\right.$; $P=0.025)$. This response is particularly marked for AM Acer and EM Betula angiosperm trees (Fig. 1b), but absent from plant-free controls across the same three $\left[\mathrm{CO}_{2}\right]_{\mathrm{a}}$ treatments $\left(F_{2,6}=0.03 ; P=0.991\right)$. For all tree species grown at $200 \mathrm{ppm}\left[\mathrm{CO}_{2}\right]_{\mathrm{a}}$, mineral surface roughness ratios were zero after correcting for the values of plant-free controls (Fig. 1b). By extension, these findings indicate that in soils beneath trees and forests experiencing low $\left[\mathrm{CO}_{2}\right]_{\mathrm{a}}$, physical mineral alteration by fungal hyphae would essentially be reduced to levels found in un-vegetated soils. In such situations biological weathering would be limited to interactions between natural populations of free-living microorganisms and their associated soil pore waters.

VSI optical profiling allows us to link hyphal colonisation of basalt grains with mineral surface alteration features on muscovite flakes in response to varying $\left[\mathrm{CO}_{2}\right]_{\mathrm{a}}$ supply to the host trees. Under AM Sequoia trees, VSI profiling of muscovite flakes revealed branched linear trenches, $\sim 0.2-0.3 \mu \mathrm{m}$ deep, that contained etch pits extending to a maximum depth of $\sim 0.5 \mu \mathrm{m}$ below the adjacent unaltered surface (Fig. $2 \mathrm{a}-\mathrm{d}$, f). These trenches share close morphological similarity with glomeromycotean (AM) fungal hyphae, including diagnostic angular projections (Fig. 2a) (Smith and Read, 2008), and correspond to features seen in minerals colonised by AM trees in the field (Quirk et al., 2012). Muscovite buried beneath AM Sequoia and Acer trees at $1500 \mathrm{ppm}\left[\mathrm{CO}_{2}\right]_{\mathrm{a}}$ also developed $\sim 50 \mu \mathrm{m}$ diameter semi-spherical depressions in the silicate crystal layers, with morphology and dimensions matching AM fungal terminal spores (Smith and Read, 2008), linked by linear channels with widths also matching those of AM fungal hyphae $(2-5 \mu \mathrm{m}$ width) (Fig. 2c, d). Spore features were independently confirmed through direct observation with conventional light microscopy (Fig. 2c inset). No such features were found in muscovite buried under the EM Betula saplings, consistent with higher EMforming basidiomycotean fungal species that produce sporulating fruit bodies rather than terminal hyphal spores. Without molecular profiling, the identity of the fungi responsible for mineral alterations is not unequivocally proven. However, given the experimental conditions in soils of relatively low organic matter content in which mycorrhizal plants were growing, it is likely that the effects observed result from mycorrhiza-driven weathering. Our VSI evidence challenges the recent assumption that AM fungi are passive components of Earth's biological weathering engine (Lambers et (a)

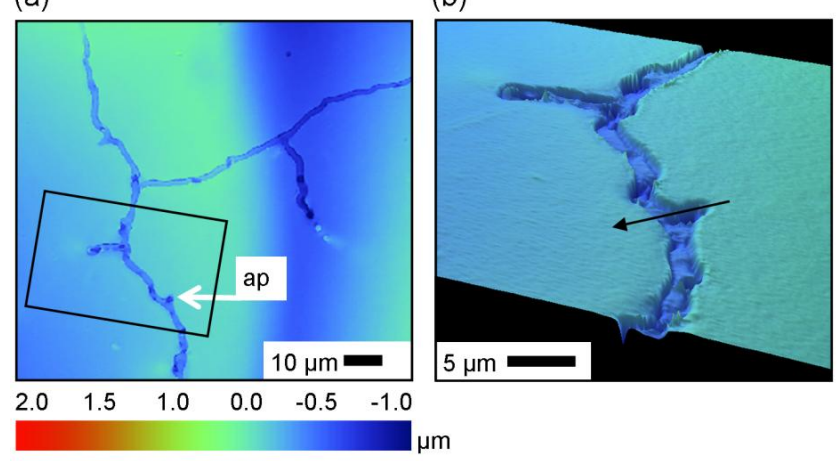

(c)

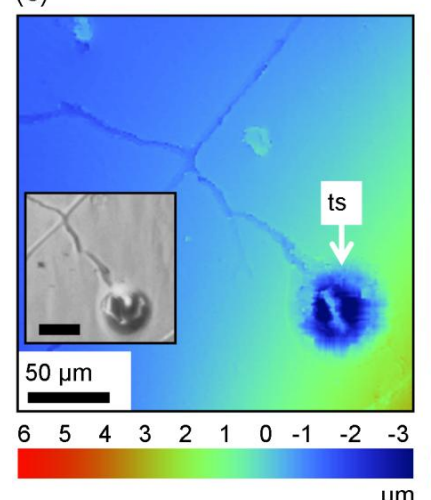

(e)

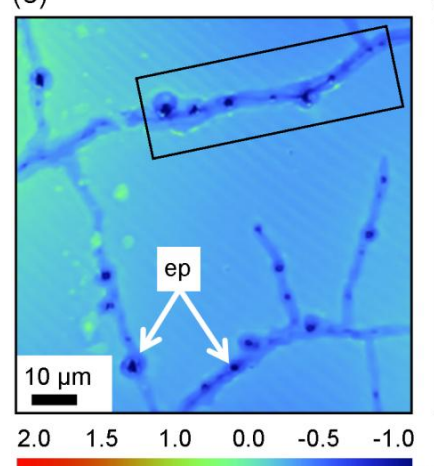

(f)

(d)
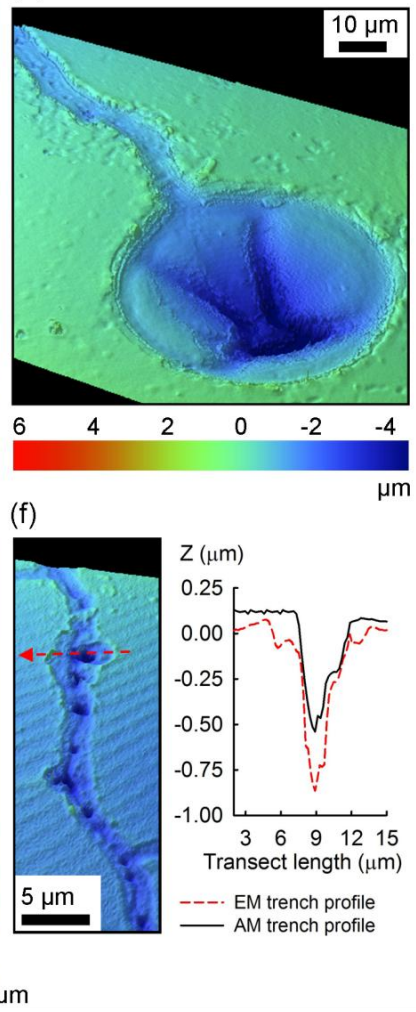

Fig. 2. Alteration of silicate mineral surfaces by symbiotic fungal hyphae. (a) Linear trench features on muscovite in an AM Sequoia treatment at $500 \mathrm{ppm}\left[\mathrm{CO}_{2}\right]_{\mathrm{a}}$ exhibiting the angular hyphal projections (ap) diagnostic of glomeromycotean (AM-forming) fungi. The area within the rectangular box in (a) is magnified and projected in 3-D in (b) to emphasise the morphology of the fungal trenches. The profile of the solid black transect arrow is plotted in (f). (c) Physical disruption of muscovite beneath AM Sequoia at $1500 \mathrm{ppm}$ $\left[\mathrm{CO}_{2}\right]_{\mathrm{a}}$ associated with a terminal spore (ts), as confirmed by light microscopy (inset; scale bar is $50 \mu \mathrm{m}$ ). (d) Surface disruption, associated with a terminal spore produced in muscovite beneath an AM Acer sapling at $1500 \mathrm{ppm}\left[\mathrm{CO}_{2}\right]_{\mathrm{a}}$. (e) Surface alteration by trenching and pitting of muscovite beneath EM Betula saplings; the area within the rectangular box is magnified in (f) to reveal morphological details of etch pits (ep) and the dashed red transect arrow is plotted. All units are micrometres. 


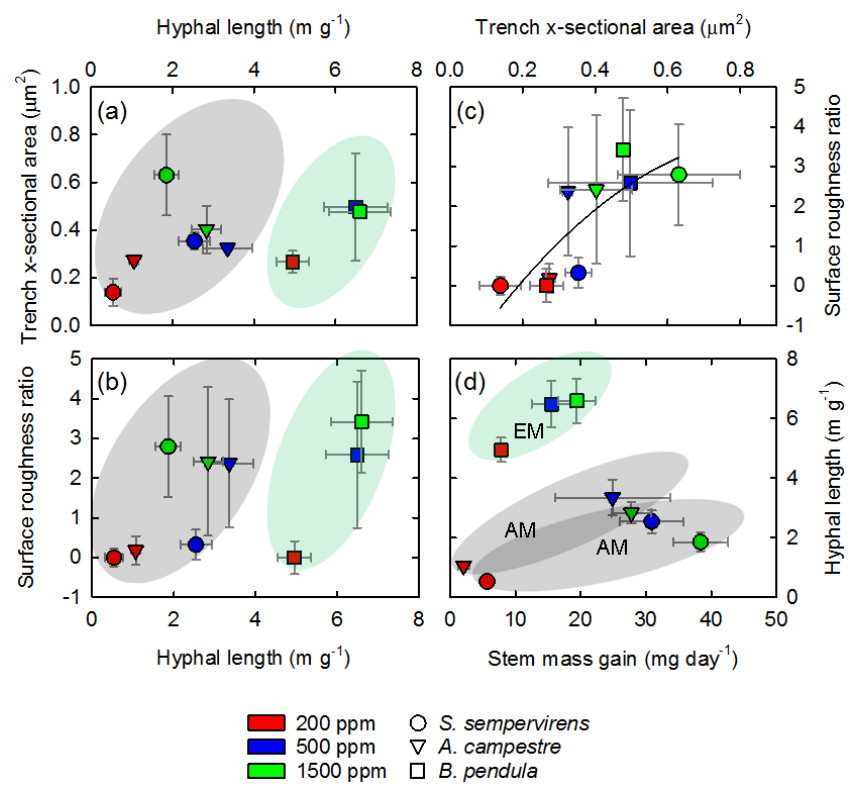

Fig. 3. $\left[\mathrm{CO}_{2}\right]_{\mathrm{a}}$-regulated hyphal trenching and mineral surface alteration. Effect of decreasing $\left[\mathrm{CO}_{2}\right]_{\mathrm{a}}$ on the relationship between hyphal length per unit mass of basalt and (a) cross-sectional area of trenches in muscovite and (b) surface roughness ratio of the mineral. Circles are Sequoia (AM), triangles are Acer (AM) and squares are Betula (EM). (c) Cross-sectional areas of hyphal trenches on muscovite flakes and surface roughness of the mineral both increase with $\left[\mathrm{CO}_{2}\right]_{\mathrm{a}}$. (d) Positive relationship between stem mass gain at different $\left[\mathrm{CO}_{2}\right]_{\mathrm{a}}$ and hyphal lengths supported by each tree species and associated with basalt grain weathering. All values are mean \pm SEM.

al., 2009), and further implicates the involvement of ancestral mycorrhizal fungi in biotic weathering processes over the past $400 \mathrm{Ma}$ (Koele et al., 2014; Quirk et al., 2012).

In addition to alteration of the exposed upper surface of the silicate sheets, some of the trench features are consistent with physical and chemical disruption by hyphal penetration between the repeating layers of the muscovite flakes. This is confirmed using VSI imaging demonstrating fungal penetration of step features in the mineral (Supplement Fig. S2), challenging recent claims that linear trench features in minerals widely reported from field studies are of totally abiotic origin (Sverdrup, 2009). Flakes recovered from beneath EM Betula saplings (Fig. 2e, f) also show extensive linear trenching punctuated with deeper pits, but with wider trenches $(3.7 \pm 0.3 \mu \mathrm{m})$ than those from AM Sequoia $(2.7 \pm 0.2 \mu \mathrm{m})$ and Acer $(3.2 \pm 0.2 \mu \mathrm{m})\left(F_{2,18}=2.77 ; P=0.072\right)$ trees.

Trenching and pitting of minerals by fungal hyphae indicates dissolution and mass loss from the mineral, as shown for biotite and chlorite weathered by EM fungi in axenic culture with host tree seedlings (Bonneville et al., 2009; Gazzè et al., 2012; Saccone et al., 2011) and in liquid culture (Balogh-Brunstad et al., 2008). Collectively, the evidence indicates that fungal attack of the mineral occurs on exposed outer surfaces and also between the sheets of muscovite. This is consistent with field observations of 3-10 $\mu \mathrm{m}$ diameter tunnels in non-phyllosilicate minerals, like feldspar and hornblende (Hoffland et al., 2003; Jongmans et al., 1997), and in silicate rocks like basalt (Cochran and Berner, 1996), that have been ascribed to the actions of EM fungi mobilising nutrients from minerals in soils beneath forested ecosystems (Blum et al., 2002; Finlay et al., 2009; Hoffland et al., 2003). Our experiments now establish this second mode of attack by AM and EM fungi on minerals, in this case involving active delamination and internal trenching of phyllosilicates by both groups of mycorrhizal fungi (Fig. 2 and Supplement Fig. S2).

\subsection{Stabilising low $\left[\mathrm{CO}_{2}\right]_{\mathrm{a}}$ feedback on biotic weathering}

Critically, our results establish that AM and EM trees growing at low $\left[\mathrm{CO}_{2}\right]_{\mathrm{a}}$ are associated with reductions in the extent of hyphal colonisation of minerals, which is further compounded by the formation of trench features on minerals with smaller cross-sectional areas that highlight less aggressive fungal-mineral interactions (Fig. 3a). The crosssectional area of fungal trenches on the muscovite were significantly smaller at $200 \mathrm{ppm}\left[\mathrm{CO}_{2}\right]_{\mathrm{a}}\left(0.23 \pm 0.03 \mu \mathrm{m}^{2}\right)$ than those at $1500 \mathrm{ppm}\left[\mathrm{CO}_{2}\right]_{\mathrm{a}}\left(0.52 \pm 0.11 \mu \mathrm{m}^{2}\right)\left(F_{2,18}=5.30\right.$; $P=0.015$ ) (Fig. 3a, c). This may reflect reduced demand for mineral nutrients by the trees and fungal partners under conditions of $\left[\mathrm{CO}_{2}\right]_{\mathrm{a}}$ starvation. Foraging mycorrhizal hyphae likely target and colonise basalt for acquisition of phosphorus and micronutrient elements from olivine, apatite or other silicate mineral inclusions in the rock. These processes are associated with the parallel dissolution of excess $\mathrm{Ca}$ and $\mathrm{Mg}$ that is not taken up by the fungi, as evidenced by the formation of calcium oxalate crystals on hyphae (Arocena et al., 2001; Tuason and Arocena, 2009). Decreased fungal colonisation of mineral grains at $200 \mathrm{ppm}\left[\mathrm{CO}_{2}\right]_{\mathrm{a}}$ is associated with diminished muscovite surface roughness ratios (Fig. 3b). The intensity of the fungal-mineral interactions indicated by the cross-sectional areas of trenches in muscovite is proportional to the surface roughness. Across all tree-mycorrhiza partnerships this relationship is linked to declining $\left[\mathrm{CO}_{2}\right]_{\mathrm{a}}$, with convergence to near-zero surface roughness ratios at $200 \mathrm{ppm}$ $\mathrm{CO}_{2}$ (Fig. 3c).

Our findings support the hypothesised "top-down" control by host trees on mineral weathering through the capture and delivery of photosynthate carbon from the canopy down to the roots and mycorrhizal hyphal tips in soils (Brantley et al., 2011). In all three tree species investigated, calculated host tree stem productivity $\left(F_{2,18}=27.7 ; P<0.0001\right.$; Fig. 3d), root biomass $\left(F_{2,18}=5.08 ; P=0.019\right)$ and total tree biomass $\left(F_{2,18}=6.41 ; P=0.008\right)$ (Fig. 4) showed significant effects of declining $\left[\mathrm{CO}_{2}\right]_{\mathrm{a}}$, particularly from 500 to $200 \mathrm{ppm}$. Most importantly, as tree productivity declines as $\left[\mathrm{CO}_{2}\right]_{\mathrm{a}}$ approaches $200 \mathrm{ppm}, \mathrm{AM}$ and EM hyphal 

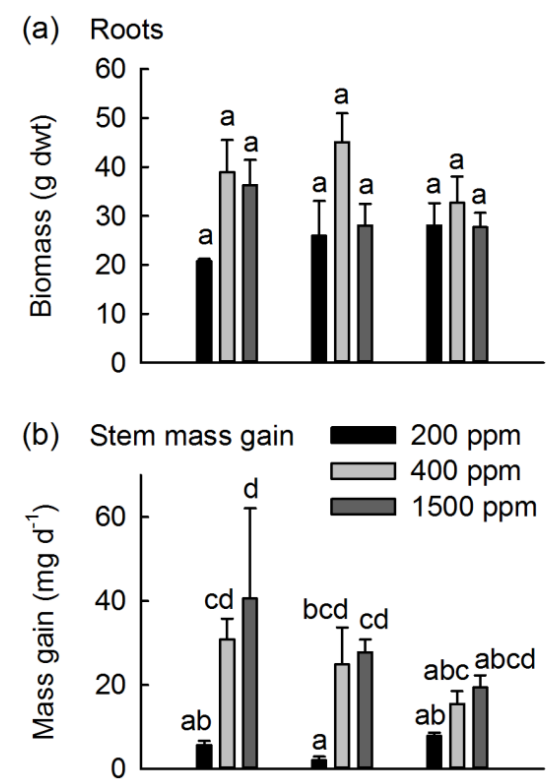

(c) Total plant weight at harvest

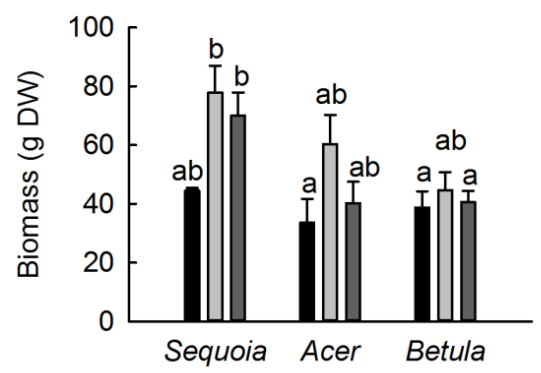

Fig. 4. Sapling biomass after the experiment. Root biomass (a), calculated stem mass gain (b) (a proxy for net primary production) and measured total plant biomass (c) at the end of the experiment. Values are mean \pm SEM $(n=3)$. Bars sharing the same letter are not statistically different at $P<0.05$ (two-way ANOVA testing for effects of species and $\left[\mathrm{CO}_{2}\right]_{\mathrm{a}}$ with Tukey multiple comparisons).

network sizes also diminish (Fig. 3d). Both hyphal network size and weathering intensity are linked along a continuum driven by the $\left[\mathrm{CO}_{2}\right]_{\mathrm{a}}$ treatments of the host trees, with low $\left[\mathrm{CO}_{2}\right]_{\mathrm{a}}$ down-regulating mineral weathering by AM and EM hyphal networks (Fig. 3a-d).

\subsection{Process-based modelling of $\mathrm{CO}_{2}$-driven biological weathering}

Simulated total basaltic $\mathrm{Ca}^{2+}, \mathrm{Mg}^{2+}$ and $\mathrm{Si}^{4+}$ dissolution fluxes from the hyphospheres of AM and EM trees over the course of the study decline markedly (three-fold) when $\left[\mathrm{CO}_{2}\right]_{\mathrm{a}}$ drops towards $200 \mathrm{ppm}$ (Fig. 5a). We focus on basalt dissolution as the most important source of continental silicate-bound $\mathrm{Ca}^{2+}$ and $\mathrm{Mg}^{2+}$ regulating long-term $\left[\mathrm{CO}_{2}\right]_{\mathrm{a}}$ (Dessert et al., 2003) and because field evidence indicates AM and EM fungi of temperate trees preferentially
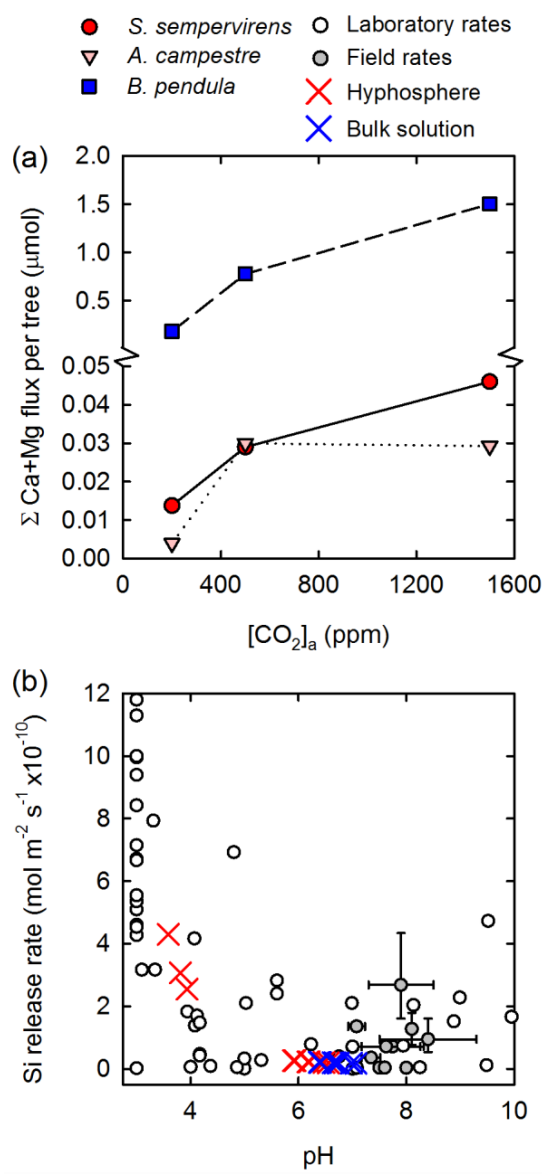

Fig. 5. Numerical simulations of $\left[\mathrm{CO}_{2}\right] \mathrm{a}$-regulated mycorrhizal fungal weathering. (a) Simulated $\left[\mathrm{CO}_{2}\right]_{\mathrm{a}}$-regulated total $\mathrm{Ca}$ and $\mathrm{Mg}$ weathering flux from basalt by AM and EM fungal networks beneath each tree over the 185 day experiment (note the axis break). (b) Simulated release of Si from basalt by the hyphosphere and bulk solution interactions for trees versus calculated $\mathrm{pH}$, compared with $\mathrm{Si}$ release rates and $\mathrm{pH}$ values from field and laboratory studies of basalt weathering (Navarre-Sitchler and Brantley, 2007).

colonise basalt grains and significantly enhance their weathering (Quirk et al., 2012). The order-of-magnitude-greater simulated dissolution fluxes from the hyphosphere of EM Betula compared to the AM trees (Fig. 5a) is driven primarily by the greater size of EM hyphal soil networks across all $\left[\mathrm{CO}_{2}\right]_{\mathrm{a}}$ treatments in our study (Fig. 1a) and the exudation of oxalate from active EM hyphae.

Reduced cation fluxes from the basalt at low $\left[\mathrm{CO}_{2}\right]_{\mathrm{a}}$ are driven by the feedback of low $\left[\mathrm{CO}_{2}\right]_{\mathrm{a}}$ on host tree productivity, which diminishes mycorrhizal hyphal network size and activity (Fig. 3). The simulated rates of basalt dissolution in the immediate vicinity of the mycorrhizal hyphae, and in the bulk soil, are well validated by comparison with rates derived from field observations of catchment-scale weathering and laboratory studies (Navarre-Sitchler and Brantley, 2007) (Fig. 5b). Earlier field studies using the same basalt that we 


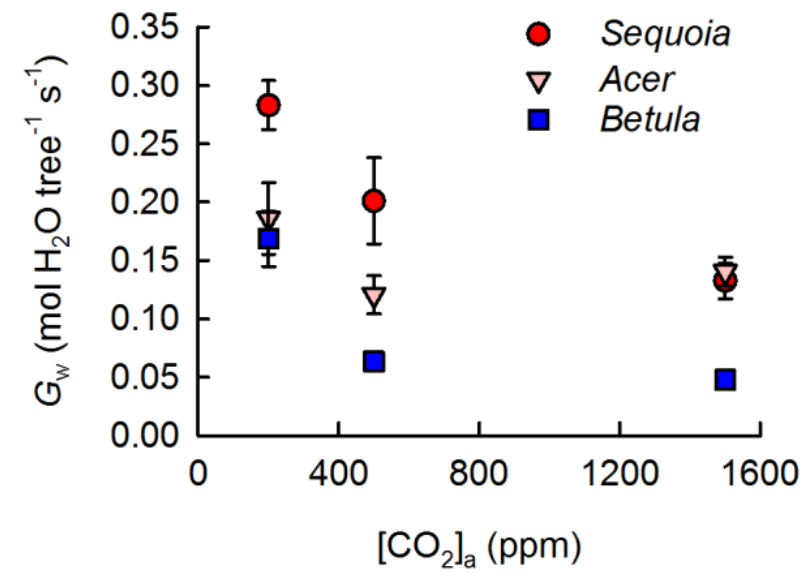

Fig. 6. $\left[\mathrm{CO}_{2}\right]_{\mathrm{a}}$-regulated canopy conductance to water vapour. Whole canopy transpiration rates $\left(G_{\mathrm{W}}\right)$ increase with declining $\left[\mathrm{CO}_{2}\right]_{\mathrm{a}}$. Values are means $\pm \operatorname{SEM} .(n=3)$.

use to assess hyphal colonisation in the present study revealed clear evidence of calcium dissolution from major silicate phases (predominantly plagioclase) in the rock (Quirk et al., 2012). Dissolution of highly reactive interstitial glass of varying composition and abundance may contribute to the weathering flux of certain elements during the early stages of basalt weathering. However, the dissolution of primary silicate mineral phases drives the $\mathrm{Ca}^{2+}$ and $\mathrm{Mg}^{2+}$ weathering flux over longer timescales (Wu et al., 2007; Gislason and Oelkers, 2003; Gislason et al., 2009).

In general, acidification of the microenvironment surrounding the hyphae accelerates weathering with a $\mathrm{pH}$ drop of 2-3 units (Fig. 5b). However, smaller hyphal networks release fewer protons into pore waters and moisture films surrounding the basalt grains, which are themselves influenced by the effect of low $\left[\mathrm{CO}_{2}\right]_{\mathrm{a}}$-driven increases in canopy transpiration rates (Fig. 6). Our results indicate that the combination of smaller mycorrhizal networks and lower proton extrusion rates into a drier hyphosphere and soil environment under low $\left[\mathrm{CO}_{2}\right]_{\text {a }}$ would create less acidic weathering conditions and lower dissolution rates of $\mathrm{Ca}^{2+}, \mathrm{Mg}^{2+}$ and other base cations. Smaller mycorrhizal soil networks under low $\left[\mathrm{CO}_{2}\right]_{\mathrm{a}}$ would effectively reduce the surface area of active hyphae interacting with mineral grains, thereby diminishing the importance of these soil microorganisms in regulating mineral weathering reactions during geologic intervals of low $\left[\mathrm{CO}_{2}\right]_{\mathrm{a}}$.

Our results indicate that the effects of $\left[\mathrm{CO}_{2}\right]_{\mathrm{a}}$ feedbacks on biological weathering rates as represented in geochemical carbon cycle models (Berner, 2004, 2006; Berner and Kothavala, 2001; Volk, 1987) may not reflect the full extent of the responses of trees together with their mycorrhizal partners to global $\left[\mathrm{CO}_{2}\right]_{\mathrm{a}}$ change, particularly during geologic intervals of low $\left[\mathrm{CO}_{2}\right]_{\mathrm{a}}$. Weathering rates associated with forested ecosystems that are dominated by AM or EM fungi cannot be assumed to respond to $\left[\mathrm{CO}_{2}\right]_{\mathrm{a}}$ variation in exactly the same way given the functional differences of these two major types of fungal partners. This highlights the need for researchers working in the field of plant-driven mineral weathering to carefully consider both the vegetation types and their mycorrhizal associations in order to better parameterise long-term geochemical carbon cycle models (Koele et al., 2014; Quirk et al., 2012).

\section{Conclusions}

Our experimental evidence and modelling results support the anticipated negative feedbacks between trees and weathering which underpin current models of global geochemical carbon cycling over Earth's recent geologic history (Berner, 2006; Volk, 1987). We report mechanistic details of biotic weathering processes that respond non-linearly to falling $\left[\mathrm{CO}_{2}\right]_{\mathrm{a}}$. In particular, we have shown that as the global $\left[\mathrm{CO}_{2}\right]_{\mathrm{a}}$ environment approaches a Cenozoic Earth system minimum of $200 \mathrm{ppm}$, it appears to act as a "carbon starvation" brake (Beerling et al., 2012) curtailing weathering by diminishing forest tree productivity and the associated intensity of fungal-mineral interactions. Our experiments have yet to account for a broad suite of soil types or characterise the role of soil nutrient status in limiting tree responses to high $\left[\mathrm{CO}_{2}\right]$ (Norby et al., 2010; Reich et al., 2006). Nevertheless, in general terms and under our experimental conditions, we have obtained evidence indicating that weathering processes and rates by forest trees and symbiotic fungi are sensitive to declining $\left[\mathrm{CO}_{2}\right]_{\mathrm{a}}$. This implies terrestrial biological processes may be important in buffering substantial $\left[\mathrm{CO}_{2}\right]_{\mathrm{a}}$ and climate change when episodes of tectonic activity increase the longterm sink for $\mathrm{CO}_{2}$ over millions of years. Such stabilising biotic feedbacks would operate in combination with the recently confirmed abiotic $\mathrm{CO}_{2}$-climate weathering feedback (Zeebe and Caldeira, 2008).

\section{Supplementary material related to this article is available online at http://www.biogeosciences.net/11/321/ 2014/bg-11-321-2014-supplement.pdf.}

\begin{abstract}
Acknowledgements. We thank Professor Sir David Read for commenting on an earlier draft of the manuscript and gratefully acknowledge a NERC award (NE/E015190/1) tied research studentship and a Leverhulme Trust research grant (RPG-250), and a NERC/World Universities Network Weathering Consortium award (NE/C521001/1). D. J. Beerling gratefully acknowledges funding for the VSI instrument from the University of Sheffield, and additional support through a Royal Society-Wolfson Research Merit Award and an ERC Advanced Grant (CDREG, 322998).
\end{abstract}

Edited by: J.-A. Subke 


\section{References}

Alberton, O., Kuyper, T. W., and Gorissen, A.: Taking mycocentrism seriously: mycorrhizal fungal and plant responses to elevated $\mathrm{CO}_{2}$, New Phytol., 167, 859-868, 2005.

Andrews, J. A. and Schlesinger, W. H.: Soil $\mathrm{CO}_{2}$ dynamics, acidification, and chemical weathering in a temperate forest with experimental $\mathrm{CO}_{2}$ enrichment, Global Biogeochem. Cycles, 15, 149162,2001

Arocena, J. M., Glowa, K. R., and Massicotte, H. B.: Calcium-rich hypha encrustations on Piloderma, Mycorrhiza, 10, 209-215, 2001.

Balogh-Brunstad, Z., Kent Keller, C., Thomas Dickinson, J., Stevens, F., Li, C. Y., and Bormann, B. T.: Biotite weathering and nutrient uptake by ectomycorrhizal fungus, Suillus tomentosus, in liquid-culture experiments, Geochim. Cosmochim. Acta, 72, 2601-2618, 2008.

Beerling, D. J. and Royer, D. L.: Convergent Cenozoic $\mathrm{CO}_{2}$ history, Nat. Geosci., 4, 418-420, 2011.

Beerling, D. J., Taylor, L. L., Bradshaw, C. D. C., Lunt, D. J., Valdes, P. J., Banwart, S. A., Pagani, M., and Leake, J. R.: Ecosystem $\mathrm{CO}_{2}$ starvation and terrestrial silicate weathering: mechanisms and global-scale quantification during the late Miocene, J. Ecol., 100, 31-41, 2012.

Berner, R. A.: The Phanerozoic carbon cycle: $\mathrm{CO}_{2}$ and $\mathrm{O}_{2}$, Oxford Univ. Press, Oxford, 2004.

Berner, R. A.: GEOCARBSULF: A combined model for Phanerozoic atmospheric $\mathrm{O}_{2}$ and $\mathrm{CO}_{2}$, Geochim. Cosmochim. Acta, 70, 5653-5664, 2006.

Berner, R. A. and Kothavala, Z.: Geocarb III: A revised model of atmospheric $\mathrm{CO}_{2}$ over Phanerozoic time, Am. J. Sci., 301, 182204, 2001.

Berner, R. A., Lasaga, A. C., and Garrels, R. M.: The carbonatesilicate geochemical cycle and its effect on atmospheric carbon dioxide over the past 100 million years, Am. J. Sci., 283, 641$683,1983$.

Blum, J. D., Klaue, A., Nezat, C. A., Driscoll, C. T., Johnson, C. E., Siccama, T. G., Eagar, C., Fahey, T. J., and Likens, G. E.: Mycorrhizal weathering of apatite as an important calcium source in base-poor forest ecosystems, Nature, 417, 729-731, 2002.

Bonneville, S., Smits, M. M., Brown, A., Harrington, J., Leake, J. R., Brydson, R., and Benning, L. G.: Plant-driven fungal weathering: Early stages of mineral alteration at the nanometer scale, Geology, 37, 615-618, 2009.

Brantley, S.L.: Kinetics of mineral dissolution, in: Kinetics of Water-Rock Interaction, edited by: Brantley, S. L., Kubicki, J. D., and White, F. A., Springer, New York, 151-210, 2008.

Brantley, S. L., Megonigal, J. P., Scatena, F. N., Balogh-Brunstad, Z., Barnes, R. T., Bruns, M. A., Van Cappellen, P., Dontsova, K., Hartnett, H. E., Hartshorn, A. S., Heimsath, A., Herndon, E., Jin, L., Keller, C. K., Leake, J. R., McDowell, W. H., Meinzer, F. C., Mozdzer, T. J., Petsch, S., Pett-Ridge, J., Pregitzer, K. S., Raymond, P. A., Riebe, C. S., Shumaker, K., Sutton-Grier, A., Walter, R., and Yoo, K.: Twelve testable hypotheses on the geobiology of weathering, Geobiology, 9, 140-165, 2011.

Brundrett, M. C.: Coevolution of roots and mycorrhizas of land plants, New Phytol., 154, 275-304, 2002.

Buss, H. L., Lüttge, A., and Brantley, S. L.: Etch pit formation on iron silicate surfaces during siderophore-promoted dissolution, Chem. Geol., 240, 326-342, 2007.
Casarin, V., Plassard, C., Souche, G., and Arvieu, J. C.: Quantification of oxalate ions and protons released by ectomycorrhizal fungi in rhizosphere soil, Agronomie, 23, 461-469, 2003.

Cochran, F. M. and Berner, R. A.: Promotion of chemical weathering by higher plants: field observations on Hawaiian basalts, Chem. Geol., 132, 71-77, 1996.

Crisp, M. D., and Cook, L. G.: Cenozoic extinctions account for the low diversity of extant gymnosperms compared with angiosperms, New Phytol., 192, 997-1009, 2011.

Dessert, C., Dupre, B., Gaillardet, J., Francois, L. M., and Allegre, C. J.: Basalt weathering laws and the impact of basalt weathering on the global carbon cycle, Chem. Geol., 202, 257-273, 2003.

Drigo, B., Pijl, A. S., Duyts, H., Kielak, A. M., Gamper, H. A., Houtekamer, M. J., Boschker, H. T. S., Bodelier, P. L. E., Whiteley, A. S., van Veen, J. A., and Kowalchuk, G. A.: Shifting carbon flow from roots into associated microbial communities in response to elevated atmospheric $\mathrm{CO}_{2}$, Proc. Natl. Acad. Sci. USA, 107, 10938-10942, 2010.

Drigo, B., Kowalchuk, G. A., Knapp, B. A., Pijl, A. S., Boschker, H. T. S., and van Veen, J. A.: Impacts of 3 years of elevated atmospheric $\mathrm{CO}_{2}$ on rhizosphere carbon flow and microbial community dynamics, Global Change Biol., 19, 621-636, 2013.

Finlay, R., Wallander, H., Smits, M., Holmstrom, S., van Hees, P., Lian, B., and Rosling, A.: The role of fungi in biogenic weathering in boreal forest soils, Fung. Biol. Rev., 23, 101-106, 2009.

Fransson, P.: Elevated $\mathrm{CO}_{2}$ impacts ectomycorrhiza-mediated forest soil carbon flow: Fungal biomass production, respiration and exudation, Fung. Ecol., 5, 85-98, 2012.

Gazzè, S. A., Saccone, L., Vala Ragnarsdottir, K., Smits, M. M., Duran, A. L., Leake, J. R., Banwart, S. A., and McMaster, T. J.: Nanoscale channels on ectomycorrhizal-colonized chlorite: Evidence for plant-driven fungal dissolution, J. Geophys. Res., 117, G00N09, doi:10.1029/2012jg002016, 2012.

Gislason, S. R. and Oelkers, E. H.: Mechanism, rates, and consequences of basaltic glass dissolution: II. An experimental study of the dissolution rates of basaltic glass as a function of $\mathrm{pH}$ and temperature, Geochim. Cosmochim. Acta, 67, 3817-3832, 2003.

Gislason, S. R., Oelkers, E. H., Eiriksdottir, E. S., Kardjilov, M. I., Gisladottir, G., Sigfusson, B., Snorrason, A., Elefsen, S., Hardardottir, J., Torssander, P., and Oskarsson, N.: Direct evidence of the feedback between climate and weathering, Earth Planet. Sci. Lett., 277, 213-222, 2009.

Hoffland, E., Giesler, R., Jongmans, A. G., and Breemen, N. v.: Feldspar tunneling by fungi along natural productivity gradients, Ecosystems, 6, 739-746, 2003.

Johansson, E. M., Fransson, P. M. A., Finlay, R. D., and van Hees, P. A. W.: Quantitative analysis of soluble exudates produced by ectomycorrhizal roots as a response to ambient and elevated $\mathrm{CO}_{2}$, Soil Biol. Biochem., 41, 1111-1116, 2009.

Jongmans, A. G., van Breemen, N., Lundstrom, U., van Hees, P. A. W., Finlay, R. D., Srinivasan, M., Unestam, T., Giesler, R., Melkerud, P. A., and Olsson, M.: Rock-eating fungi, Nature, 389, 682-683, 1997.

Koele, N., Dickie, I. A., Blum, J. D., Gleason, J. D., and de Graaf, L.: Ecological significance of mineral weathering in ectomycorrhizal and arbuscular mycorrhizal ecosystems from a fieldbased comparison, Soil Biology and Biochemistry, 69, 63-70, 2014. 
Lambers, H., Mougel, C., Jaillard, B., and Hinsinger, P.: Plantmicrobe-soil interactions in the rhizosphere: an evolutionary perspective, Plant Soil, 321, 83-115, 2009.

Landeweert, R., Hoffland, E., Finlay, R. D., Kuyper, T. W., and van Breemen, N.: Linking plants to rocks: ectomycorrhizal fungi mobilize nutrients from minerals, Trends Ecol. Evol., 16, 248-254, 2001.

Lüttge, A., Bolton, E. W., and Lasaga, A. C.: An interferometric study of the dissolution kinetics of anorthite; the role of reactive surface area, Am. J. Sci., 299, 652-678, 1999.

Malhi, Y., Baldocchi, D., and Jarvis, P.: The carbon balance of tropical, temperate and boreal forests, Plant, Cell Environ., 22, 715$740,1999$.

Navarre-Sitchler, A. and Brantley, S.: Basalt weathering across scales, Earth Planet. Sci. Lett., 261, 321-334, 2007.

Norby, R. J., Warren, J. M., Iversen, C. M., Medlyn, B. E., and McMurtrie, R. E.: $\mathrm{CO}_{2}$ enhancement of forest productivity constrained by limited nitrogen availability, Proc. Natl. Acad. Sci. USA, 107, 19368-19373, doi:10.1073/pnas.1006463107, 2010.

Nye, P.: Changes of $\mathrm{pH}$ across the rhizosphere induced by roots, Plant Soil, 61, 7-26, 1981.

Pagani, M., Caldeira, K., Berner, R., and Beerling, D. J.: The role of terrestrial plants in limiting atmospheric $\mathrm{CO}_{2}$ decline over the past 24 million years, Nature, 460, 85-88, 2009.

Pagani, M., Huber, M., Liu, Z., Bohaty, S. M., Henderiks, J., Sijp, W., Krishnan, S., and DeConto, R. M.: The role of carbon dioxide during the onset of Antarctic glaciation, Science, 334, 12611264, 2011

Pritchard, S. G., Strand, A. E., McCormack, M.L., Davis, M. A., and Oren, R.: Mycorrhizal and rhizomorph dynamics in a loblolly pine forest during 5 years of free-air- $\mathrm{CO}_{2}$-enrichment, Global Change Biol., 14, 1252-1264, 2008.

Quirk, J., Beerling, D. J., Banwart, S. A., Kakonyi, G., RomeroGonzalez, M. E., and Leake, J. R.: Evolution of trees and mycorrhizal fungi intensifies silicate mineral weathering, Biol. Lett., 8, 1006-1011, 2012.

Reich, P. B., Hobbie, S. E., Lee, T., Ellsworth, D. S., West, J. B., Tilman, D., Knops, J. M. H., Naeem, S., and Trost, J.: Nitrogen limitation constrains sustainability of ecosystem response to $\mathrm{CO}_{2}$, Nature, 440, 922-925, 2006.

Rosling, A., Lindahl, B. D., and Finlay, R. D.: Carbon allocation to ectomycorrhizal roots and mycelium colonising different mineral substrates, New Phytol., 162, 795-802, 2004.

Saccone, L., Gazzè, S., Duran, A., Leake, J., Banwart, S., Ragnarsdóttir, K., Smits, M., and McMaster, T.: High resolution characterization of ectomycorrhizal fungal-mineral interactions in axenic microcosm experiments, Biogeochemistry, 111, 411-425, 2011.

Smith, S. E. and Read, D. J.: Mycorrhizal Symbiosis, $3^{\text {rd }}$ ed., Academic Press, Amsterdam, London, 2008.
Smits, M. M., Bonneville, S., Benning, L. G., Banwart, S. A., and Leake, J. R.: Plant-driven weathering of apatite - the role of an ectomycorrhizal fungus, Geobiology, 10, 445-456, 2012.

Sverdrup, H.: Chemical weathering of soil minerals and the role of biological processes, Fungal Biology Reviews, 23, 94-100, 2009.

Taylor, L. L., Leake, J. R., Quirk, J., Hardy, K., Banwart, S. A., and Beerling, D. J.: Biological weathering and the long-term carbon cycle: integrating mycorrhizal evolution and function into the current paradigm, Geobiology, 7, 171-191, 2009.

Taylor, L. L., Banwart, S. A., Leake, J. R., and Beerling, D. J.: Modeling the evolutionary rise of ectomycorrhiza on sub-surface weathering environments and the geochemical carbon cycle, Am. J. Sci., 311, 369-403, 2011.

Taylor, L. L., Banwart, S. A., Valdes, P. J., Leake, J. R., and Beerling, D. J.: Evaluating the effects of terrestrial ecosystems, climate and carbon dioxide on weathering over geological time: a global-scale process-based approach, Phil. Trans. R. Soc. London Ser. B, 367, 565-582, 2012.

Tuason, M. M. S. and Arocena, J. M.: Calcium oxalate biomineralization by Piloderma fallax in response to various levels of calcium and phosphorus, Appl. Environ. Microbiol., 75, 70797085, 2009.

van Hees, P., Rosling, A., Essén, S., Godbold, D., Jones, D., and Finlay, R.: Oxalate and ferricrocin exudation by the extramatrical mycelium of an ectomycorrhizal fungus in symbiosis with Pinus sylvestris, New Phytol., 169, 367-378, 2006.

Volk, T.: Feedbacks between weathering and atmospheric $\mathrm{CO}_{2}$ over the last 100 million years, Am. J. Sci., 287, 763-779, 1987.

Wallander, H., Göransson, H., and Rosengren, U.: Production, standing biomass and natural abundance of ${ }^{15} \mathrm{~N}$ and ${ }^{13} \mathrm{C}$ in ectomycorrhizal mycelia collected at different soil depths in two forest types, Oecologia, 139, 89-97, 2004.

Wikström, N., Savolainen, V., and Chase, M. W.: Evolution of the angiosperms: calibrating the family tree, Proc. R. Soc. London Ser. B, 268, 2211-2220, 2001.

Wu, L., Jacobson, A. D., Chen, H.-C., and Hausner, M.: Characterization of elemental release during microbe-basalt interactions at T2 $8^{\circ} \mathrm{C}$, Geochim. Cosmochim. Acta, 71, 2224-2239, 2007.

Yoder, R. E., Odhiambo, L. O., and Wright, W. C.: Effects of vaporpressure deficit and net-irradiance calculation methods on accuracy of standardized Penman-Monteith equation in a humid climate, J. Irrig. Drain. Engin., 131, 228-237, 2005.

Zeebe, R. E. and Caldeira, K.: Close mass balance of long-term carbon fluxes from ice-core $\mathrm{CO}_{2}$ and ocean chemistry records, Nat. Geosci., 1, 312-315, 2008.

Zhang, Q., Wang, C., Wang, X., and Quan, X.: Carbon concentration variability of 10 Chinese temperate tree species, Forest Ecology and Management, 258, 722-727, 2009. 